\title{
Predicting global entrepreneurship: An exploratory study
}

\author{
Teresa Torres-Coronas \\ María-Arántzazu Vidal-Blasco \\ Universitat Rovira i Virgili. Spain. \\ teresatorres@urv.cat \\ mariaarantzazu.vidal@urv.cat
}

Received: 3/9/2020

Accepted: 1/12/2020

Published: 5/7/2021

\begin{abstract}
Globalization provides international career opportunities and options, such as entrepreneurship. Entrepreneurship education is currently promoted in both national and European educational strategies. For university students, the viability of this career option depends on their own motivations, perceived competencies, and professional objectives. This study uses a structural equations model analyses the factors that affect the intention to create an international company. It focuses on how intercultural skills, cognitive cultural intelligence, entrepreneurial self-efficacy, and linguistic competence affects students' motivation to create a company with an international vocation. The results of the study show that proficiency in a foreign language, language competence, and entrepreneurial self-efficacy are relevant factors. The research also discusses the implications of these results for teaching in higher education institutions. There is a need to update graduates' employability skills and the competences that future teachers must acquire.
\end{abstract}

Keywords: entrepreneurship; entrepreneurial intention; cognitive cultural intelligence; entrepreneurial self-efficacy; language skills

\section{Resum. Predicció d'una emprenedoria global. Un estudi exploratori}

La globalització brinda oportunitats i opcions professionals internacionals, com l'emprenedoria global. L'educació en emprenedoria es promociona tant en les estratègies educatives nacionals com en les europees. Això ha suposat que en els darrers anys l'interès per promoure l'educació en emprenedoria hagi augmentat. Per als estudiants universitaris la viabilitat d'aquesta opció de carrera depèn de les seves pròpies motivacions, de les competències percebudes i dels objectius professionals. El present estudi analitza, a través d'un model d'equacions estructurals, els factors que afecten la intenció de crear una empresa internacional. En particular, se centra en com les competències interculturals, les habilitats cognitives culturals, l'autoeficàcia emprenedora i les competències lingüístiques afecten la motivació dels estudiants per crear una empresa amb vocació internacional. Els resultats de l'estudi realitzat mostren que tant el domini d'una tercera llengua com les habilitats del llenguatge i l'autoeficàcia emprenedora són factors rellevants. La recerca també discuteix les implicacions d'aquests resultats per a l'ensenyament en les institucions d'educació superior. Es necessari actualitzar les competències per a l'ocupabilitat dels graduats i també les competències que els futurs docents han d'adquirir.

Paraules clau: emprenedoria; intenció emprenedora; intel.ligència cultural cognitiva; autoeficàcia empresarial; competències lingüístiques 


\title{
Resumen. Predicción de un emprendimiento global. Un estudio exploratorio
}

La globalización brinda oportunidades y opciones profesionales internacionales, como el emprendimiento. La educación en emprendimiento se promociona en las estrategias educativas nacionales y europeas. Para los estudiantes universitarios la viabilidad de esta opción de carrera depende de sus propias motivaciones, de las competencias percibidas y de los objetivos profesionales. El presente estudio analiza, a través de un modelo de ecuaciones estructurales, los factores que afectan a la intención de crear una empresa internacional. En particular, se centra en cómo las competencias interculturales, las habilidades cognitivas culturales, la autoeficacia emprendedora y las competencias lingüísticas afectan la motivación de los estudiantes para crear una empresa con vocación internacional. Los resultados del estudio realizado muestran que tanto el dominio de una tercera lengua como las habilidades del lenguaje y la autoeficacia emprendedora son factores relevantes. La investigación también discute las implicaciones de estos resultados para la enseñanza en las instituciones de educación superior. Es necesario actualizar las competencias para la ocupabilidad de los graduados y también las competencias que los futuros docentes deben adquirir.

Palabras clave: emprendimiento; intención emprendedora; inteligencia cultural cognitiva; autoeficacia empresarial; competencias lingüísticas

\author{
Summary \\ 1. Introduction 5. Conclusions \\ 2. Background and theoretical basis \\ Bibliographical references \\ 3. Design and methodology \\ 4. Validation of hypotheses \\ and main results
}

\section{Introduction}

Business creation drives economic growth and regional development (Carree \& Thurik, 2010; Fritsch, 2011; Zampetakis, Kafetsios, Bouranta, Dewett \& Moustakis, 2009). Consequently, recent years have seen growing interest in entrepreneurial training as an instrument for facilitating this growth (Fritsch \& Kublina, 2018) and enhancing the attitudes, knowledge, and skills associated with business success (Nabi, Walmsley, Liñán, Akhtar \& Neame, 2018).

Numerous studies (e.g. Ahmetoglu, Leutner \& Chamorro, 2011; O’Boyle, Humphrey, Pollack, Hawver \& Story, 2011; Wei, Liu \& Sha, 2019) have analysed the factors behind an entrepreneur's intention to set up a company. Entrepreneurial intention is the 'self-acknowledged conviction by a person that they intend to start a new business venture and consciously plan to do so at some point in the future' (Thompson, 2009, p. 676).

Do Paço, Matos, Raposo, Gouveia \& Dinis (2013) and Sánchez, Ward, Hernández \& Florez (2017) focus on two approaches when analysing entre- 
preneurial intention, one that addresses personal characteristics and another that addresses behaviour. The first focuses on the personality of the entrepreneur (Dinis, do Paço, Ferreira, Raposo \& Gouveia, 2013), emotional intelligence (Ahmetoglu et al., 2011; Neghabi, Yousefi \& Rezvani, 2011) and entrepreneurial self-efficacy (Liñán \& Chen, 2009; Zampetakis et al., 2009). The second focuses on behaviour and uses the Entrepreneurial Event Model (EEM: Shapero \& Sokol, 1982) and Ajzen's Theory of Planned Behaviour (TPB; 1991; 2005) to analyse the origin of the entrepreneur's intention. In the EEM, entrepreneurial intention depends on perceived viability and opportunity in starting a business and the entrepreneur's propensity to act. The TPB, on the other hand, focuses on attitudes and perceived behavioural control.

The greater the perceived self-efficacy, the more favourable the attitude towards business creation (Doanh \& Bernat, 2019; Morales-Alonso, PabloLerchundi \& Núñez-Del-Río, 2016). In the digital era, entrepreneurship involves establishing new companies by creating synergies with new technologies (Oumlil \& Juiz, 2018), that is, it involves not merely setting up a company on the Internet but incorporating information technologies into the process involved in creating the value of the organization.

However, what happens when the intention is to create a company that is open to international markets? In this case, the factors involved in an entrepreneur's intention to create a company must be combined with those that are involved in his or her intention to begin an international career. This professional orientation has a strong vocational component (Lee, Porfeli \& Hirschi, 2016). At the same time, learning foreign languages and developing cross-disciplinary competencies encourage $85 \%$ of students to increase their interest in pursuing an international professional career (European Commission, 2014). Intercultural competence plays a key role since it influences the effectiveness of relationships in a diverse global environment (McFarlin \& Sweeney, 2018).

In this paper, we use the principles of Azjen model's $(1991 ; 2005)$ to analyse the factors behind an entrepreneur's intention to create an international company. The main aim is to incorporate the results for competence development to have a positive effect on entrepreneurial intention. In the first section, we present the background and review the literature, with special reference to entrepreneurial self-efficacy and the competencies that influence international mobility. In this section, we also define the topic to be investigated, our hypotheses, and the proposed model. Next, we describe our methodology, discuss our results, and draw conclusions. The results show that cognitive cultural intelligence, language proficiency, and entrepreneurial self-efficacy have a positive impact on an entrepreneur's motivation for setting up a project with an international vocation. 


\section{Background and theoretical basis}

\subsection{Entrepreneurial self-efficacy}

Bandura (1997) defines entrepreneurial self-efficacy as 'the belief in one's ability to produce designated levels of performance or a desired outcome that can exert influence over events that affect one's life' (p. 72). Self-efficacy is the key to predicting entrepreneurial intent (Laguna, 2013; Moriano, Palací \& Morales, 2006) because without the perception of skill, there is no entrepreneurial behaviour. Motivational beliefs refer 'not only to the exercise of control over an action but also to the self-regulation of thought processes, motivation, and emotional and psychological states' (Bandura, 1997, p. 36). Entrepreneurial self-efficacy is therefore included in models that study a person's motivation for global entrepreneurship.

Studies such as those by Laviolette, Lefebvre \& Brunel (2012), Prahdan and Nath (2012), Fernández-Pérez, Montes-Merino, Rodríguez-Ariza \& Alonso (2019) and Fadzil et al. (2019) have shown that emotions affect entrepreneurial self-efficacy - a variable related to gender roles (Mueller \& Conway Dato-on, 2013) and cultural barriers (Shinnar, Giacomin \& Janssen, 2012).

From the above considerations we formulate the following hypothesis:

H1: Entrepreneurial self-efficacy has a positive effect on a person's motivation for setting up a global business.

\subsection{Competencies that affect global entrepreneurship}

Career decision-making describes or explains the choices one makes in relation to one's career throughout one's working life. In this process, it is important to identify which factors affect decision-making and to understand what level of impact these factors have on individual choices. Earlier studies have associated foreign language knowledge, intercultural competence, and cognitive cultural intelligence with international mobility and interest in embarking on a professional career in the international arena.

Below we discuss the main factors that are considered to influence a student's motivation for creating an international start-up. Our study analyses these factors to integrate its results in entrepreneurship education as proposed by Fayolle (2018) and Morris and Ligouri (2016).

\section{Factor 1. Accredited language knowledge}

Because today's labour market is globalized, demanding, and competitive, there is a need for language training. Linguistic competence is understood as the ability to know and use every component of the language correctly (Rico, 2005, p. 80). Barbero, Maestro, Pitcaim \& Saiz (2008) define this competence as the 'ability to express and interpret thoughts, feelings, and facts orally and in writing and to interact linguistically and appropriately in a wide range of 
social and cultural contexts' (p. 11). Therefore, language knowledge is a form of cultural competence that affects a person's professional performance in intercultural environments (Tsaur \& Tu, 2019).

However, developing good linguistic competence it is not sufficient. According to Salaberri (2007), 'the development of communicative competence is insufficient for responding to the demands of the new multicultural and multilingual societies. The aim of language teaching and learning should be to develop intercultural speakers' (p. 61). This means that the intercultural competence, or the ability of individuals who do not share the same culture, ethnicity, language, or other important variables to relate to others and communicate effectively with them (Rico, 2005, p. 80), must be taken into account. People with a higher level of intercultural competence show more respect and empathy towards other cultures, interact in a less biased way (Lustig \& Koester, 2006), and are better able to learn new languages.

\section{Factor 2. Cognitive cultural intelligence}

According to Earley and Ang (2003), cultural intelligence may be defined as 'one's ability to adapt effectively to new cultural contexts' (p. 59) in order to interact effectively (Ang \& Van Dyne, 2008). Key to making successful interactions in international markets (Alon \& Higgins, 2005), cultural intelligence comprises those facets of metacognitive, cognitive, motivational, and behavioural intelligence that positively influence the efficacy of interactions between various cultural environments (Ang, Van Dyne \& Tan, 2011). Of these four components, in this study we focus on cognitive cultural intelligence (cognitive CQ), which can be defined as a person's level of understanding of culture and of the role of culture in shaping how to do business and how to interact with others across different cultural contexts. Developing cognitive CQ is closely linked to having previous international experience, though not all studies report a positive relationship between the two (Michailova \& Ott, 2018).

Given that the inability to interact with other cultures can affect the success of professional activity, knowing how to develop this competence is key because of its effects on individuals' sociocultural and psychological adaptation to a new cultural context (Prebistero, 2016; 2017). The greater one's cultural intelligence, therefore, the greater the probability of embarking on an international career. In projects that involve people from other countries, cultural intelligence is key to improving performance and satisfaction (Henderson, Stackman \& Lindekilde, 2018).

Based on the above considerations, we can formulate the following hypotheses:

H2: Language competence has a positive effect on a person's motivation for setting up a global business.

H3: Cognitive cultural intelligence has a positive effect on a person's motivation for setting up a global business or an international project. 


\section{Factor 3. Contextual factors}

In addition to the above factors, contextual factors are also important, such as a person's field of knowledge and work experience. As regards the field of knowledge, Hassan and Wafa (2012) showed that students who take science degrees have stronger entrepreneurial intentions than those who pursue degrees in business, the arts, or humanities. Although interest in entrepreneurship is not specific to students in the business world (Shinnar, Pruett \& Toney, 2009), the lack of entrepreneurship training does affect students who do not receive curricular training in entrepreneurship (Zhang, Duysters \& Cloodt, 2014). The active participation of students in entrepreneurship education courses increases their interest in starting a business by twofold (Martin \& Iucub, 2014). Therefore, we included field of study as a contextual variable to understand how the model is influenced by factors 1 and 2, and by training.

Similarly, Lazear's Jack-of-All-Trades theory (2005) shows that experience in several profiles increases the probability of becoming an entrepreneur (Miralles, Giones \& Riverola, 2015). Moreover, greater experience is associated with greater entrepreneurial competence (Camuffo, Gerli \& Gurbita, 2012).

By incorporating contextual factors into our study, we formulated the following hypothesis:

H4: Contextual factors have a direct and positive effect on a person's motivation for setting up a global business.

\section{Design and methodology}

\subsection{Participants}

This study uses a questionnaire sent to undergraduate students at a Spanish public university during the 2016-2017 academic year. The final number of participants was $502,78.8 \%$ of whom were women. Of the final sample, $58.6 \%$ had no professional experience, while $43.7 \%$ had completed a company internship as part of their degree programme; $35 \%$ were studying social sciences, which include education sciences and law; 17\% were studying architecture or engineering; $12.2 \%$ were studying sciences; $23.5 \%$ were studying health sciences; and $2.4 \%$ were studying arts or humanities.

\subsection{Measurement instruments}

Below we describe the scales and the psychometric properties of the measurement instruments used in this study. The questionnaires employed a 5-point Likert scale with the following options: 1 (strongly disagree), 2 (disagree), 3 (somewhat disagree), 4 (agree), and 5 (strongly agree).

Intention to set up a global business. This variable measured the participants' perception regarding their intention to set up and run a new business. To 
measure intention, we used the questionnaire developed by Liñán \& Chen (2009) adapted to international entrepreneurship.

Entrepreneurial self-efficacy. We used the entrepreneurial self-efficacy scale by De Noble, Jung \& Ehrlich (1999), which was validated for use in Spain by Moriano et al. (2006). The final version comprises 23 items.

Cognitive cultural intelligence. This variable measures knowledge of the norms and practices of other cultures acquired through education and personal experience (Ng, Van Dyne \& Ang, 2012; Ng, Kee \& Ramayah, 2016). It includes knowledge of economic, sociolinguistic, and interpersonal relations systems, as well as basic knowledge of cultural values similar to those described in Hofstede's model of cultural differences (2001). This variable was chosen based on the idea that people with a high level of cognitive cultural intelligence are better able to understand intercultural differences and similarities (Brislin, Worthley \& MacNab, 2006). Here, we used the cognitive cultural intelligence scale developed by Ang et al. (2007).

Foreign language competence. In this section, the students indicated their level of English in accordance with the Common European Framework of Reference for Languages (CEFRL; Council of Europe, 2001). The CEFRL divides foreign language competence into six levels: basic user (A1 breakthrough/beginner and A2 waystage/elementary); independent user (B1 threshold/intermediate and B2 vantage/upper-intermediate); and proficient user ( $\mathrm{C} 1$ effective operational proficiency/ advanced and $\mathrm{C} 2$ mastery/proficiency). Of the participants in our study, $2.6 \%$ reported that they were basic users, $6.7 \%$ said they had reached a B1 level, $28.5 \%$ stated they had reached a B2 level, $40 \%$ said they had reached a $\mathrm{C} 1$ level, and $22.2 \%$ reported they had reached a C2 level. Therefore, most participants had a higher-than-intermediate level.

\subsection{Validation of the final model}

\subsubsection{The PLS-SEM technique}

The data were analysed using SmartPLS 3.0 and the partial least squares structural equation modelling (PLS-SEM) technique, which is becoming popular in the field of entrepreneurship (Hernández-Perlines, 2016). The sample size was as recommended by Byrne (2010) since it exceeded the minimum number of 200. The psychometric properties of the constructs and the relationships between constructs were examined to check the validity and reliability of the results.

The model considers that cognitive cultural intelligence, foreign language proficiency, and the perception of one's own abilities (entrepreneurial selfefficacy scale), as well as work experience and field of study, have a direct impact on an individual's intention to set up a global business. Figure 1 (which includes no indirect effects) summarizes the proposed model. 
Figure 1. Proposed model

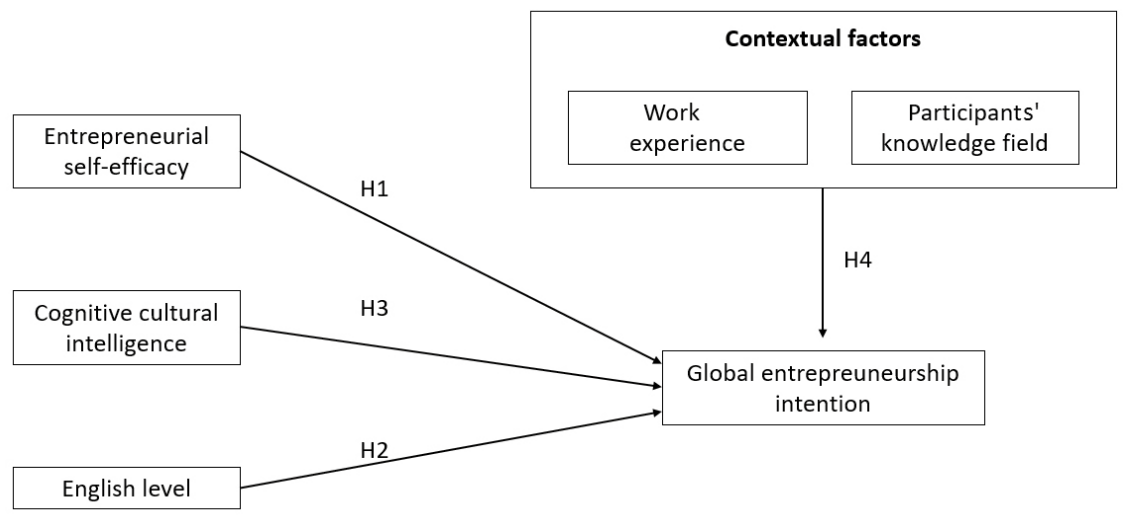

Source: Own elaboration.

\subsubsection{Validity of the measurement model}

To analyse validity and reliability, the measurement model was first evaluated by analysing reliability, convergent validity, and discriminant validity.

To assess convergent validity, we used confirmatory factor analysis (see Figure 2 with the outer loading factors) and average variance extracted (AVE; see Table 1). For intention to create an international company and entrepreneurial self-efficacy, it was not necessary to refine the data since the values of all loads in the construct (Figure 2) were greater than 0.7. For cognitive culture intelligence, two indicators with loads below 0.7 were refined. Once these two items were discarded, the AVE for all constructs was above 0.5 (Esfandiar, Sharifi-Tehrani, Pratt \& Altinay, 2019). These constructs therefore explained over half the variance of their indicators.

Table 1. Model reliability

\begin{tabular}{lcccc}
\hline & $\begin{array}{c}\text { Cronbach's } \\
\text { alpha }\end{array}$ & rho_A & $\begin{array}{c}\text { Composite } \\
\text { reliability }\end{array}$ & $\begin{array}{c}\text { Average variance } \\
\text { extracted (AVE) }\end{array}$ \\
\hline $\begin{array}{l}\text { Entrepreneurial } \\
\text { self-efficacy }\end{array}$ & 0.874 & 0.884 & 0.805 & 0.615 \\
$\begin{array}{l}\text { Global entrepreneurship } \\
\text { intention }\end{array}$ & 0.915 & 0.923 & 0.836 & 0.746 \\
\hline $\begin{array}{l}\text { Cognitive cultural } \\
\text { intelligence }\end{array}$ & 0.830 & 0.881 & 0.866 & 0.521 \\
\hline
\end{tabular}

Source: Own elaboration.

To assess discriminant validity, we used the heterotrait-monotrait (HTMT) ratio of correlations (see Table 2). The values for all constructs met the thresholds recommended by Hair, Hult, Ringle \& Sarstedt (2017). Cross-load analysis also suggested discriminant validity. 
Table 2. Discriminant validity of the measurement model (HTMT values)

\begin{tabular}{lccc}
\hline & $\begin{array}{c}\text { Entrepreneurial } \\
\text { self-efficacy }\end{array}$ & $\begin{array}{c}\text { Global } \\
\text { entrepreneurship } \\
\text { intention }\end{array}$ & $\begin{array}{c}\text { Cognitive cultural } \\
\text { intelligence }\end{array}$ \\
\hline $\begin{array}{l}\text { Entrepreneurial } \\
\text { self-efficacy }\end{array}$ & 0.053 & & \\
$\begin{array}{l}\text { Global entrepreneurship } \\
\text { intention }\end{array}$ & 0.366 & 0.418 & \\
$\begin{array}{l}\text { Cognitive cultural } \\
\text { intelligence }\end{array}$ & 0.362 & 0.420 & 0.424 \\
\hline
\end{tabular}

Source: Own elaboration.

After evaluating the reliability and validity of the measurement model, we validated the structural model and verified the hypotheses.

\section{Validation of hypotheses and main results}

In our exploratory study, we used PLS-SEM. This technique is suitable for analysing our hypotheses and is now widely used in models for analysing entrepreneurial intention, such as those in the study by Estafindiar et al. (2019). To validate the model, we conducted a bootstrap analysis with 500 samples.

The model was evaluated using the method proposed by Yeh, Wang, Hsu $\&$ Lin (2020) and the coefficient of determination $\left(\mathrm{R}^{2}\right)$ was analysed (Table 3$)$. For intention to create a global business, an $\mathrm{R}^{2}$ value of 0.287 had a slight-tomoderate effect (Hair et al., 2017).

Table 3. Coefficient of determination of the constructs

\begin{tabular}{lccccc}
\hline & $\begin{array}{c}\mathbf{R}^{2} \text { original } \\
\text { sample }\end{array}$ & $\begin{array}{c}\text { Sample } \\
\text { mean }\end{array}$ & $\begin{array}{c}\text { Standard } \\
\text { deviation }\end{array}$ & $\begin{array}{c}\mathbf{T} \\
\text { statistics }\end{array}$ & $\begin{array}{c}\mathbf{P} \\
\text { values }\end{array}$ \\
\hline $\begin{array}{l}\text { Entrepreneurial } \\
\text { self-efficacy }\end{array}$ & 0.113 & 0.116 & 0.031 & 3.635 & 0.000 \\
$\begin{array}{l}\text { Global entrepreneurship } \\
\text { intention }\end{array}$ & 0.287 & 0.294 & 0.033 & 8.590 & 0.000 \\
$\begin{array}{l}\text { Cognitive cultural } \\
\text { intelligence }\end{array}$ & 0.142 & 0.147 & 0.037 & 3.892 & 0.000 \\
\hline
\end{tabular}

Source: Own elaboration.

Figure 2 shows the results of the analyses with the path coefficients, which are significant at the 0.01 level. Entrepreneurial self-efficacy had a positive impact on global entrepreneurship $(B=0.310 ; p<0.01)$, as did level of English $(\beta=0.276 ; p<0.01)$ and cultural cognitive intelligence $(\beta=0.177$; $p<0.01)$. Hypotheses $\mathrm{H} 1$ to $\mathrm{H} 3$ are therefore supported by the model. However, this was not the case with the contextual variables, which were not significant, so hypothesis $\mathrm{H} 4$ was rejected. 
Figure 2. Path coefficients and total effects

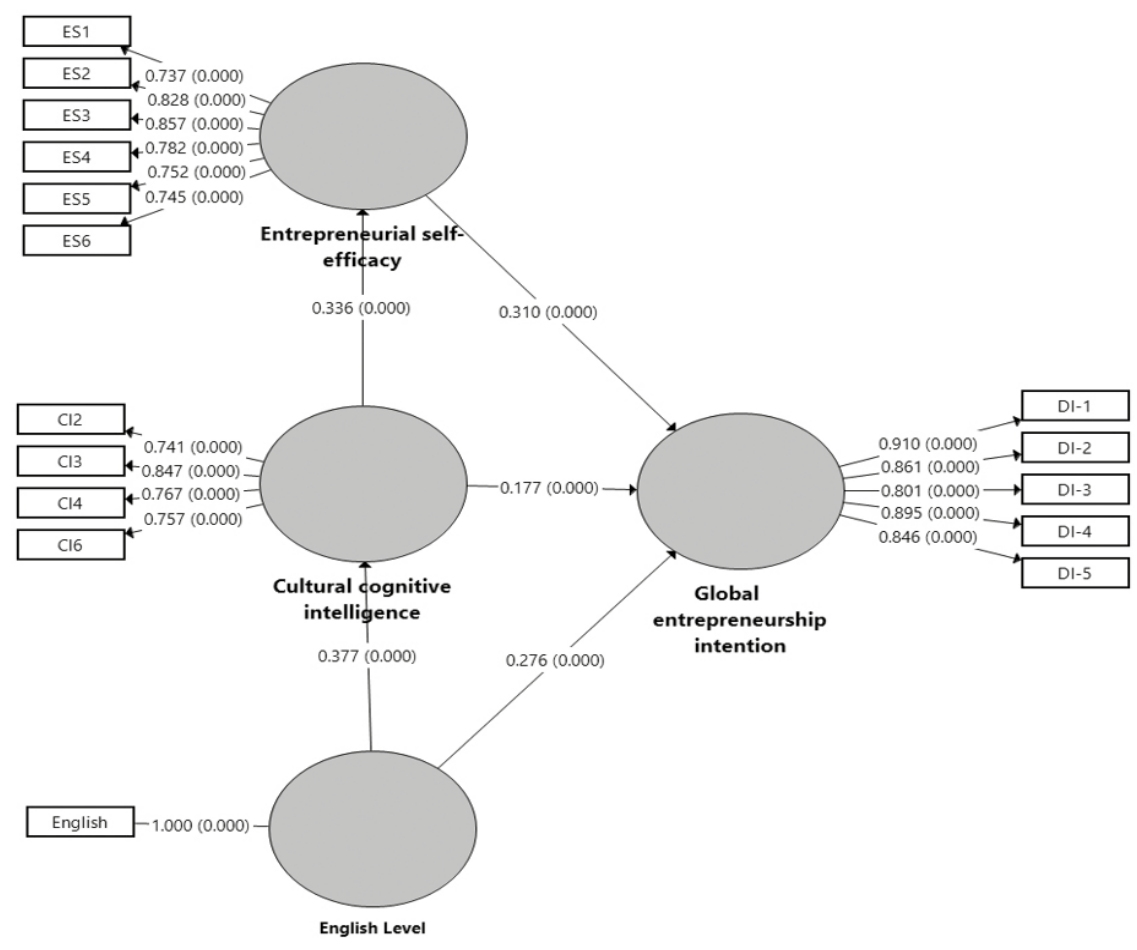

Source: Own elaboration.

The relationship between entrepreneurial self-efficacy and intention to create a company has been highlighted in numerous previous studies, although this relationship is mediated by attitude towards entrepreneurship and perceived behavioural control (Doanh \& Bernat, 2019; Utamin, 2017). Perceived confidence, in terms of self-efficacy, is key in the context of international careers (Joardar \& Weisang, 2019; Prebistero \& Quita, 2017). Cognitive cultural competence explains the behaviour of the participants in our study, though to a lesser degree than expected.

Table 4. Total, direct, and indirect effects

\begin{tabular}{lccc}
\hline & Total effect & Indirect effect & Direct effect \\
\hline Entrepreneurial self-efficacy & 0.310 & & \\
English level & 0.383 & 0.106 & 0.276 \\
\hline Cognitive cultural intelligence & 0.281 & 0.104 & 0.177 \\
\hline
\end{tabular}

Source: Own elaboration. 
Table 4 shows the total, direct, and indirect effects. As can be seen in the table, the level of English has an indirect effect on global entrepreneurship through cultural cognitive intelligence, which in turn has an indirect effect through entrepreneurial self-efficacy.

Our results show that, in line with the model of Azien (1991), the selfperception of one's abilities is important for explaining factors that affect global entrepreneurship. In this case, the model confirms that foreign language proficiency is the second most important factor (more important than cognitive cultural intelligence), while entrepreneurial self-efficacy is the main factor.

\section{Conclusions}

The economy needs entrepreneurs to identify market opportunities and innovations that provide solutions to social problems. Teaching entrepreneurship is a challenge for most professors from non-business faculties (Martin $\&$ Iucub, 2014). Indeed, entrepreneurship is still an up-and-coming subject in teacher education (Redford, 2015). This reality needs to change to support innovations in education such as building education technology start-ups or leading innovation in educational organizations and companies.

Despite the efforts made, education does not always manage to promote the entrepreneurial intention that would encourage international projects. Not only language skills are important if higher education institutions wish to train global entrepreneurs. People with a higher cognitive cultural intelligence (Ang \& Van Dyne, 2008) are not so reticent about participating in intercultural meetings since they have more confidence in their abilities. In this regard, we have shown that studying a foreign language influences cultural intelligence - which is consistent with the fact that this competence can be acquired through training (Azevedo \& Shane, 2019; Wang, Heppner, Wang \& Zhu, 2015).

This study presents certain limitations. The first of these involves the methodology used to test the relationships between the constructs (SME). The reliability of the scales was less accurate than we expected, which suggests that the results should be interpreted with a certain degree of caution. It should also be noted that not every component included in the instrument was significant. We therefore believe that this model is an initial contribution that should be analysed in other contexts and possibly with other contrast tests to make it more generally applicable.

The geographical and temporal scope of the study (using data from one university focusing on one academic year and not including, for example, longitudinal data for several years) may also be a limitation when generalizing the results. As Ruiz-Rosa, Gutiérrez-Taño \& García-Rodríguez (2020) have argued, contextual factors such as time affect entrepreneurial intention. Entrepreneurial intention also changes by country due to social norms, educational level, or socio-political factors (Fei, Yu, Minru \& Mingde, 2019; Teixeira, Casteleiro, Rodrigues \& Guerra, 2018). 
It could also be of interest to analyse students' behaviour based on the type of degree completed, as it is likely to differ from one degree to another. For example, social sciences and law students may be more likely to start an international business than arts and humanities students.

Similar studies incorporating the gender perspective should also be explored since gender affects an individual's willingness to embark on an international career (Tharenou, 2008). Given the fewer women entrepreneurs (Díaz-García \& Jiménez-Moreno, 2010) and evidence of different levels of competence between men and women (Alcaraz-Rodríguez, Alvárez \& Villasana, 2014), incorporating the gender perspective into the model is a pending task. Other demographic variables (such as age) could also be considered due to their effects on an individual's intention to go abroad (Selmer \& Lauring, 2010). We should also remember the limitations of the sample itself, which exclusively comprised university students (Esfandiar et al., 2019; Prebistero \& Quita, 2017).

The results of this study show that universities must develop their students' ability to act in a suitable and flexible way when encountering actions, attitudes, and expectations of people from other cultures. The requirement that students should graduate with a B2 or C1 certificate in a foreign language is not sufficient to guarantee their employability in a global world. Curricular requirements for study periods in foreign countries may play an important role in promoting a global mindset. Therefore, the governing bodies of universities should support initiatives aimed at promoting multicultural exchange, as such measures would enable students to develop their cognitive cultural intelligence.

\section{Bibliographical references}

Ahmetoglu, G.; Leutner, F. \& Chamorro, T. (2011). EQ-nomics: Understanding the relationship between individual differences in trait emotional intelligence and entrepreneurship. Personality and Individual Differences, 51, 1028-1033. <http://dx.doi.org/10.1016/j.paid.2011.08.016>

Ajzen, I. (1991). The theory of planned behavior. Organizational Behavior and Human Decision Processes, 50(2), 179-211. <http://dx.doi.org/10.1016/0749-5978(91)90020-T>

- (2005). Attitudes, personality, and behavior. New York, NY: McGraw-Hill Education.

Alcaraz-Rodríguez, R.; Alvárez, M. M. \& Villasana, M. (2014). Developing entrepreneurial competences in students in the life sciences: The Lifetech AdVenture program. On the Horizon, 22(3), 182-191. <http://dx.doi.org/10.1108/OTH-11-2013-0053>

Alon, I. \& Higgins, J. M. (2005). Global leadership success through emotional and cultural intelligences. Business Horizons, 48(6), 501-512. <http://dx.doi.org/doi:10.1016/j.bushor.2005.04.003>

ANG, S. \& VAN Dyne, L. (2008). Conceptualization of cultural intelligence: Definition, distinctiveness, and nomological network. In S. ANG \& L. VAN Dyne (Eds.). Handbook of cultural intelligence: Theory, measurement, and applications (pp. 3-15). New York, NY: Sharpe. 
Ang, S.; VAn Dyne, L. \& TAN, M. L. (2011). Cultural intelligence. In R. J. STeRnBerG \& S. B. Kaufman (Eds.). Cambridge handbook on intelligence (pp. 582-602). New York, NY: Cambridge Press.

Ang, S.; Van Dyne, L.; Koh, C.; NG, K. Y.; Templer, K.; Tay, C. \& Chandrasekar, N. A. (2007). Cultural intelligence: Its measurement and effects on cultural judgment and decision making, cultural adaptation and task performance. Management and Organization Review, 3(3), 335-371.

<http://dx.doi.org/10.1111/j.1740-8784.2007.00082.x>

Azevedo, A. \& Shane, M. J. (2019). A new training program in developing cultural intelligence can also improve innovative work behavior and resilience: A longitudinal pilot study of graduate students and professional employees. The International Journal of Management Education, 17(3), 100303.

<http://dx.doi.org/10.1016/j.ijme.2019.05.004>

Bandura, A. (1997). Self-efficacy: The exercise of control. New York, NY: Freeman.

Barbero, J.; Maestro, A.; Pitcairn, C. \& Saiz, A. (2008). Las competencias básicas en el área de lenguas extranjeras. Cuadernos de Educación de Cantabria [Basic competencies in foreign languages. Education notebooks of Cantabria]. Gobierno de Cantabria. Consejería de Educación.

Brislin, R.; Worthley, R. \& Macnab, B. (2006). Cultural intelligence: Understanding behaviors that serve people's goals. Group \& Organization Management, 31(1), 40-55. <http://dx.doi.org/10.1177/1059601105275262>

Byrne, B. M. (2010). Structural equation modeling with AMOS: Basic concepts, applications and programming. New York, NY: Routledge.

Camuffo, A.; Gerli, F. \& GubitTa, P. (2012). Competencies matter: Modeling effective entrepreneurship in Northeast of Italy small firms. Cross Cultural Management, $19(1), 48-66$. <http://dx.doi.org/10.1108/13527601211195628>

Carree, M. A. \& Thurik, A. R. (2010). The impact of entrepreneurship on economic growth. In D. B. Audretsch \& Z. J. Acs (Eds.). Handbook of Entrepreneurship Research (pp. 557-594). Berlin: Springer Verlag.

Council of Europe (2001). Common European Framework of Reference for Languages: Learning, teaching, assessment, CEFRL. Council of Europe.

De Noble, A.; Jung, D. \& Ehrlich, S. (1999). Entrepreneurial self-efficacy: The development of a measure and its relationship to entrepreneurial actions. Paper presented at the Conference on Frontiers of Entrepreneurship Research, Waltham, United States.

Díaz-García, M. C. \& Jiménez-Moreno, J. (2010). Entrepreneurial intention: The role of gender. International Entrepreneurship Management Journal, 6, 261-283. <http://dx.doi.org/10.1007/s11365-008-0103-2>

Dinis, A.; do Paço, A.; Ferreira, J.; Raposo, M. \& Gouveia, R. (2013). Psychological characteristics and entrepreneurial intentions among secondary students. Education + Training, 55(8/9), 763-780. <http://dx.doi.org/10.1108/ET-06-2013-0085>

Do Paço, A.; Matos, J.; Raposo, M.; Gouveia, R. \& Dinis, A. (2013). Entrepreneurial intentions: Is education enough? International Entrepreneurship and Management Journal, 50, 57-75.

<https://doi.org/10.1007/s11365-013-0280-5> 
Doanh, D. C. \& Bernat, T. (2019). Entrepreneurial self-efficacy and intention among Vietnamese students: A meta-analytic path analysis based on the theory of planned behavior. Procedia Computer Science, 159, 2447-2460.

<http://dx.doi.org/10.1016/j.procs.2019.09.420>

EARley, P. C. \& ANG, S. (2003). Cultural intelligence: Individual interactions across cultures. Palo Alto: Stanford University Press.

Esfandiar, K.; Sharifi-Tehrani, M.; Pratt, S. \& Altinay, L. (2019). Understanding entrepreneurial intentions: A developed integrated structural model approach. Journal of Business Research, 94, 172-182. <http://dx.doi.org/10.1016/j.jbusres.2017.10.045>

European CoMmission (2014). The Erasmus impact study effects of mobility on the skills and employability of students and the internationalisation of higher education institutions. Luxembourg: Publications Office of the European Union.

Fadzil, A. F. M.; Hashim, U. J.; Yaacob, M. R.; Sallehudin, H.; Muhayiddin, M. N.; Mukhtar, D.; Salleh, F. \& Mohamad, R. (2019). Entrepreneurial psychology and competencies: Some perspectives from e-commerce entrepreneurs in Malaysia. Journal of Entrepreneurship, Business and Economics, 7(2), 31-79.

FAYOLLE, A. (2018). A research agenda for entrepreneurship education. Cheltenham, UK: Elgar Publishing Limited.

Fei, H.; Yu, S.; Minru, L. \& Mingde, Q. (2019). Model of the entrepreneurial intention of university students in the Pearl River Delta of China. Frontiers in Psychology, 10, 916. <http://dx.doi.org/10.3389/fpsyg.2019.00916>

Fernández-Pérez, V.; Montes-Merino, A.; Rodríguez-Ariza, L. \& Alonso, P. (2019). Emotional competencies and cognitive antecedents in shaping student's entrepreneurial intention: The moderating role of entrepreneurship education. International Entrepreneurship and Management Journal, 15(1), 281-305. <http://dx.doi.org/10.1007/s11365-017-0438-7>

Fritsch, M. (2011). New business formation and regional development: A survey and assessment of the evidence. Foundations and Trends $(R)$ in Entrepreneurship, 9(3), 249-364. <http://dx.doi.org/10.1561/0300000043>

Fritsch, M. \& Kublina, S. (2018). Entrepreneurship, growth, and regional growth regimes. In J. Leitão; H. Alves; N. Krueger \& J. PArk (Eds.). Entrepreneurial, innovative and sustainable ecosystems: Applying quality of life research (best practices) (pp. 3-34). Switzerland: Springer, Cham.

Hair, J. F.; Hult, G. T.; Ringle, C. \& Sarstedt, M. (2017). A primer on partial least squares structural equation modelling (PLS-SEM) (2nd ed.). Thousand Oaks, CA: Sage.

Hassan, R. A. \& Wafa, S. A. (2012). Predictors towards entrepreneurial intention: A Malaysian case study. Asian Journal of Business and Management Sciences, 1(11), 1-10.

Henderson, L. S.; Stackman, R. W. \& Lindekilde, R. (2018). Why cultural intelligence matters on global project teams. International Journal of Project Management, 36(7), 954-967.

<http://dx.doi.org/10.1016/j.ijproman.2018.06.001>

Hernández-Perlines, F. (2016). Entrepreneurial orientation in hotel industry: Multi-group analysis of quality certification. Journal of Business Research, 69(10), 4714-4724. <http://dx.doi.org/10.1016/j.jbusres.2016.04.019> 
Hofstede, G. (2001). Culture's consequences: Comparing values, behaviours, institutions, and organizations across nations. Thousand Oaks, CA: Sage.

JoArdar, A. \& WeIsANG, G. (2019). A multi-country study of factors influencing expatriate career intentions. Journal of International Management, 25(2), 100660. <http://dx.doi.org/10.1016/j.intman.2018.12.001>

Laguna, M. (2013). Self-efficacy, self-esteem, and entrepreneurship among the unemployed. Journal of Applied Social Psychology, 43(2), 253-262. <http://dx.doi.org/10.1111/j.1559-1816.2012.00994.x>

Laviolette, E. M.; Lefebvre, M. R. \& Brunel, O. (2012). The impact of story bound entrepreneurial role models on self-efficacy and entrepreneurial intention. International Journal of Entrepreneurial Behavior \& Research, 18(6), 720-742. <http://dx.doi.org/10.1108/13552551211268148>

LAzEAR, E. P. (2005). Entrepreneurship. Journal of Labor Economics, 23(4), 649-680.

Lee, B.; Porfeli, E. J. \& Hirschi, A. (2016). Between- and within-person level motivational precursors associated with career exploration. Journal of Vocational Behavior, 92, 125-134. <http://dx.doi.org/10.1016/j.jvb.2015.11.009>

LiÑÁN, F. \& CHEN, Y. W. (2009). Development and cross-cultural application of a specific instrument to measure entrepreneurial intentions. Entrepreneurship Theory and Practice, 33(3), 593-617.

Lustig, M. \& Koester, J. (2006). Intercultural competence interpersonal communication across cultures (5th ed.) Boston, MA: Pearson.

Martin, C. \& Iucub, R. B. (2014). Teaching entrepreneurship to educational sciences students. Procedia - Social and Behavioral Sciences, 116, 4397-4400. <http://dx.doi.org/10.1016/j.sbspro.2014.01.954>

McFarlin, D. \& SweEney, P. (2018). International organizational behavior: Transcending borders and cultures (2nd ed.). New York, NY: Routledge.

Michailova, S. \& Отт, D. (2018). Linking international experience and cultural intelligence development. Journal of Global Mobility, 6(1), 59-78. <http://dx.doi.org/10.1108/JGM-07-2017-0028>

Miralles, F.; Giones, F. \& Riverola, C. (2015). Evaluating the impact of prior experience in entrepreneurial intention. International Entrepreneurship and Management Journal, 12, 791-813. <http://dx.doi.org/10.1007/s11365-015-0365-4>

Morales-Alonso, G.; Pablo-Lerchundi, I. \& Núñez-Del-Río, M. C. (2016). Entrepreneurial intention of engineering students and associated influence of contextual factors. Revista de Psicología Social, 31(1), 75-108. <http://dx.doi.org/10.1080/02134748.2015.1101314>

Moriano, J. A.; Palací, F. J. \& Morales, J. F. (2006). Adaptación y validación en España de la escala de Autoeficacia Emprendedora [Adaptation and validation in Spain of the Entrepreneurial Self-Efficacy scale]. Revista de Psicología Social, 21(1), 51-64.

Morris, M. H. \& Ligouri, E. (2016). Annals of entrepreneurship education and pedagogy. Annals in entrepreneurship education series. Cheltenham, UK: Elgar Publishing Limited.

Mueller, S. L. \& Conway Dato-on, M. C. (2013). A cross cultural study of genderrole orientation and entrepreneurial self-efficacy. International Entrepreneurship and Management Journal, 9(1), 1-20.

Nabi, G.; Walmsley, A.; Liñán, F.; Akhtar, I. \& Neame, C. (2018). Does entrepreneurship education in the first year of higher education develop entrepreneurial 
intentions? The role of learning and inspiration. Studies in Higher Education, 43(3), 452-467. <http://dx.doi.org/10.1080/03075079.2016.1177716>

Neghabi, S.; Yousefi, M. \& Rezvani, M. (2011). Emotional intelligence and entrepreneurial behavior: Development of personal aspects of intentions model. International Proceedings of Economics and Development Research, 21, 27-31.

Ng, H. S.; Kee, D. M. H. \& Ramayah, T. (2016). The role of transformational leadership, entrepreneurial competence and technical competence on enterprise success of owner-managed SMEs. Journal of General Management, 42(1), $23-43$. $<$ http://dx.doi.org/10.1177/030630701604200103>

NG, K-Y.; VAN Dyne, L. \& Ang, S. (2012). Cultural intelligence: A review, reflections, and recommendations for future research. In A. M. RyAN; F. T. L. LEONG \& F. L. OswaLD (Eds.). Conducting multinational research: Applying organizational psychology in the workplace (pp. 29-58). Washington, DC: American Psychological Association.

O’Boyle, E. H. Jr.; Humphrey, R. H.; Pollack, J. M.; Hawver, T. H. \& Story, P. A. (2011). The relation between emotional intelligence and job performance: A meta-analysis. Journal of Organizational Behavior, 32(5), 788-818. $<$ http://dx.doi.org/10.1002/job.714>

Oumlit, R. \& Juiz, C. (2018). Acceptance of tourism e-entrepreneurship application to educational Balearic island context. Journal of Entrepreneurship Education, 21(1), 1-16.

Prahdan, R. K. \& Nath, P. (2012). Perception of entrepreneurial orientation and emotional intelligence: A study on Indiaas future techno-managers. Global Business Review, 13(1), 89-108. $<\mathrm{http} / /$ dx.doi.org/10.1177/097215091101300106>

Presbitero, A. (2016). Culture shock and reverse culture shock: The moderating role of cultural intelligence in international students' adaptation. International Journal of Intercultural Relations, 53, 28-38. <http://dx.doi.org/10.1016/j.ijintrel.2016.05.004>

- (2017). Religious expatriates' cultural intelligence and adaptation: The role of intrinsic motivation for successful expatriation. Journal of Global Mobility, 5(2), 146-157. <http://dx.doi.org/10.1108/JGM-09-2016-0041>

Presbitero, A. \& Quita, C. (2017). Expatriate career intentions: Links to career adaptability and cultural intelligence. Journal of Vocational Behavior, 98, 18-126. $<$ https://doi.org/10.1016/j.jvb.2016.11.001>

REDFoRD, D. T. (2015). Entrepreneurial teacher training in Europe: an overview of European policies and developments. Journal for Educators, Teachers and Trainers, $6(2), 17-34$.

Rico, A. M. (2005). De la competencia intercultural en la adquisición de una segunda lengua o lengua extranjera: conceptos, metodología y revisión de métodos [On intercultural competence in second or foreign language acquisition: Concepts, methodology, and review of methods]. Porta Linguarum, 3, 79-94.

Ruiz-Rosa, I.; Gutiérrez-TaÑo, D. \& García-Rodríguez, F. J. (2020). Social entrepreneurial intention and the impact of COVID-19 pandemic: A structural model. Sustainability, 12, 6970. $<$ http://dx.doi.org/10.3390/su12176970>

SALABERRI, M. S. (2007). Competencia comunicativa intercultural [Intercultural communicative competence]. Opiniones, 61-76. 
Sánchez, J. C.; Ward, A.; Hernández, B. \& Florez, J. (2017). Educación emprendedora: Estado del arte [Entrepreneurship education: State of the art]. Propósitos y Representaciones, 5(2), 401-473. <http://dx.doi.org/10.20511/pyr2017.v5n2.190>

Selmer, J. \& Lauring, J. (2010). Self-initiated academic expatriates: Inherent demographics and reasons to expatriate. European Management Review, 7(3), 169-179. <https://doi.org/10.1057/emr.2010.15>

Shapero, A. \& Sokol, L. (1982). Social dimensions of entrepreneurship. In C. Kent; D. Sexton \& K.H. Vesper (Eds.). The encyclopaedia of entrepreneurship (pp. 77-90). Englewood Cliffs: Prentice-Hall.

Shinnar, R. S.; Giacomin, O. \& Janssen, F. (2012). Entrepreneurial perceptions and intentions: The role of gender and culture. Entrepreneurship Theory and Practice, 36(3), 465-493. <https://doi.org/10.1111\%2Fj.1540-6520.2012.00509.x>

Shinnar, R.; Pruett, M. \& Toney. B. (2009). Entrepreneurship education: Attitudes across campus. Journal of Education for Business, 84(3), 151-159.

Teixeira, S. J.; Casteleiro, C. M. L.; Rodrigues, R. G. \& Guerra, M. D. (2018). Entrepreneurial intentions and entrepreneurship in European countries. International Journal of Innovation Science, 10(1), 22-42. <https://doi.org/10.1108/IJIS-07-2017-0062>

Tharenou, P. (2008). Disruptive decisions to leave home: Gender and family differences in expatriation choices. Organizational Behavior and Human Decision Processes, 105(2), 183-200. <https://doi.org/10.1016/j.obhdp.2007.08.004>

Thompson, E. R. (2009). Individual entrepreneurial intent: Construct clarification and development of an internationally reliable metric. Entrepreneurship Theory and Practice, 33(3), 669-694. <https://doi.org/10.1111\%2Fj.1540-6520.2009.00321.x>

Tsaur, S. H. \& Tu, J. H. (2019). Cultural competence for tour leaders: Scale development and validation. Tourism Management, 71, 9-17. <http://dx.doi.org/10.1016/j.tourman.2018.09.017>

Utamin, C. W. (2017). Attitude, subjective norms, perceived behavior, entrepreneurship education and self-efficacy towards entrepreneurial intention university student in Indonesia. European Research Studies Journal, 20(24), 475-495.

WANG, K. T.; Heppner, P. P.; Wang, L. \& ZhU, F. (2015). Cultural intelligence trajectories in new international students: Implications for the development of crosscultural competence. International Perspectives in Psychology: Research, Practice, Consultation, 4(1), 51. $<$ https://doi.org/10.1037/ipp0000027>

WeI, X.; Liu, X. \& SHA, J. (2019). How does the entrepreneurship education influence the students' innovation? Testing on the multiple mediation model. Frontiers in Psychology, 10, 1557. <http://dx.doi.org/10.3389/fpsyg.2019.01557>

Yeh, C. H.; Wang, S.; Hsu, J. W. \& Lin, S. J. (2020). Predicting individuals' digital autopreneurship: Does educational intervention matter? Journal of Business Research, 106, 35-45. <https://doi.org/10.1016/j.jbusres.2019.08.020>

Zampetakis, L. A.; Kafetsios, K.; Bouranta, N.; Dewett, T. \& Moustakis, V. S. (2009). On the relationship between emotional intelligence and entrepreneurial 
attitudes and intentions. International Journal of Entrepreneurial Behaviour \& Research, 15(6), 595-618.

$<$ http://dx.doi.org/10.1108/13552550910995452>

Zhang, Y.; Duysters, G. M. \& Cloodt, M. M. A. H. (2014). The role of entrepreneurship education as a predictor of university students' entrepreneurial intention. International Entrepreneurship and Management Journal, 10(3), 623-641. $<$ http://dx.doi.org/10.1007/s11365-012-0246-z> 